\title{
THE
}

\section{Effectiveness of Advanced Nitrogen-Removal Onsite Wastewater Treatment Systems in a New England Coastal Community}

\author{
Bianca Ross \\ University of Rhode Island \\ Kevin P. Hoyt \\ University of Rhode Island \\ George W. Loomis \\ University of Rhode Island \\ José A. Amador \\ University of Rhode Island, jamador@uri.edu
}

Follow this and additional works at: https://digitalcommons.uri.edu/nrs_facpubs

The University of Rhode Island Faculty have made this article openly available.

Please let us know how Open Access to this research benefits you.

This is a pre-publication author manuscript of the final, published article.

Terms of Use

This article is made available under the terms and conditions applicable towards Open Access

Policy Articles, as set forth in our Terms of Use.

\section{Citation/Publisher Attribution}

Ross, B.N., Hoyt, K.P., Loomis, G.W. et al. Effectiveness of Advanced Nitrogen-Removal Onsite Wastewater Treatment Systems in a New England Coastal Community. Water Air Soil Pollut 231, 543 (2020).

https://doi.org/10.1007/s11270-020-04911-5

Available at: https://doi.org/10.1007/s11270-020-04911-5

This Article is brought to you for free and open access by the Natural Resources Science at DigitalCommons@URI. It has been accepted for inclusion in Natural Resources Science Faculty Publications by an authorized administrator of DigitalCommons@URI. For more information, please contact digitalcommons-group@uri.edu. 


\title{
Effectiveness of Advanced Nitrogen-Removal Onsite Wastewater Treatment Systems in a New England Coastal Community
}

\author{
Bianca N. Ross*, Kevin P. Hoyt, George W. Loomis, and Jose A. Amador \\ *Corresponding author: Bianca N. Ross \\ E-mail: bpeixoto10@uri.edu \\ T: (401) 874-2902 \\ ORCID: 0000-0001-6231-9437
}

Bianca N. Ross, Kevin P. Hoyt, Jose A. Amador

Affiliation/address: Laboratory of Soil Ecology and Microbiology, University of Rhode Island, 1 Greenhouse Rd., Kingston, RI 02881, USA

Bianca N. Ross:

E-mail: bpeixoto10@uri.edu

Kevin P. Hoyt:

E-mail: kevin_hoyt@uri.edu

Jose A. Amador

E-mail: jamador@uri.edu

George W. Loomis

Affiliation/address: New England Onsite Wastewater Training Center, University of Rhode Island, 102 Coastal Institute, 1 Greenhouse Rd., Kingston, RI 02881, USA

E-mail: gloomis@uri.edu

Keywords: Onsite wastewater treatment systems, wastewater, nitrogen, biological nitrogen removal

\section{Acknowledgements}

This work was funded by the USDA National Institute of Food and Agriculture, Hatch Multi-State NE 1545 Project [accession number 1007770] and by a grant (00A000128-0) awarded by the U. S. Environmental Protection Agency to Jose Amador and George Loomis at the University of Rhode Island.

We thank our regulatory partners at the Rhode Island Department of Environmental Management and the Town of Charlestown Office of Wastewater Management (Matt Dowling, Charlestown Onsite Wastewater Program Manager) for assisting with technical aspects of the project and procuring study sites. We also thank the Charlestown homeowners who allowed us to study their advanced N-removal OWTS. Special thanks go to Shawn Barron, Alissa Cox, Evelyn Rhodes, Alicia Boucher, Jonathan Ludovico, Fidaa Janoudi, Connor Silverman, Owen Placido, and Lincoln Dark for their technical and field support.

Although the information in this paper has been funded wholly or in part by the U. S. Environmental Protection Agency, it has not undergone the Agency's publications review 
process and therefore may not necessarily reflect the views of the Agency; no official endorsement should be inferred. The viewpoints expressed here do not necessarily represent those of the Town of Charlestown, the Rhode Island Department of Environmental Management, or the U. S. Environmental Protection Agency, nor does mention of trade names, commercial products, or causes constitute endorsement or recommendation for use.

\section{Declarations}

Funding: USDA National Institute of Food and Agriculture; Hatch Multi-State NE 1545 Project [accession number 1007770]; grant \# 00A000128-0 awarded by the U. S. Environmental Protection Agency to Jose Amador and George Loomis at the University of Rhode Island

Conflicts of interest/Competing interests: There are no conflicts of interest or competing interests associated with this research.

Ethics approval: Not applicable

Consent to participate: All authors consented to participated in this research.

Consent for publication: All authors consent to the publication of this research.

Availability of data and material: All results discussed in this paper accurately reflect the data obtained in this study.

Code availability: Not applicable. 


\begin{abstract}
Wastewater is a major source of nitrogen $(\mathrm{N})$ to groundwater and coastal waterbodies, threatening both environmental and public health. Advanced N-removal onsite wastewater treatment systems (OWTS) are used to reduce effluent $\mathrm{N}$ concentration; however, few studies have assessed their effectiveness. We evaluated the total $\mathrm{N}(\mathrm{TN})$ concentration of effluent from 50 advanced N-removal OWTS in Charlestown, Rhode Island, USA for three years. We quantified differences in effectiveness as a function of N-removal technology and home occupancy pattern (seasonal vs. year-round use), and examined the relationship between wastewater properties and TN concentration. RX30 systems produced the lowest median TN concentration (mg N/L) (13.2), followed by FAST (13.4), AX20 (14.9) and Norweco (33.8). Compliance with the state's regulatory standard for effluent TN concentration (19 mg N/L) was highest for RX30 systems (78\%), followed by AX20 (73\%), FAST (67\%), and Norweco (0\%). Occupancy pattern did not affect effluent TN concentration. Variation in TN concentration was driven by ammonium and nitrate for all technologies, and also by temperature for FAST and $\mathrm{pH}$ for Norweco. Median daily (g N/d) and annual (kg N/yr) N loads were significantly higher for year-round (5.3 and 2.3) than for seasonal (3.7 and 0.41) systems, likely due to differences in volume of wastewater treated. Our results suggest that advanced N-removal OWTS vary in their compliance with the state regulatory standard for effluent $\mathrm{TN}$ and can withstand long periods of non-use without compromising effectiveness. Nevertheless, systems used year-round do produce a higher daily and annual $\mathrm{N}$ load than seasonally-used systems.
\end{abstract}




\section{Introduction}

Effluent from onsite wastewater treatment systems (OWTS) is an important source of nitrogen (N) to coastal watersheds (Valiela et al., 2010). Because $\mathrm{N}$ is a limiting nutrient in coastal ecosystems, increased inputs of $\mathrm{N}$ to groundwater and poorly flushed coastal systems promote eutrophication, which results in anoxia that kills fish and shellfish. Eutrophication can also boost the growth of toxic algal species, which threatens public health (Carpenter et al., 1998; Gan, 2002; Sohail \& Adeloju, 2016). The harmful effects of eutrophication have become increasingly evident in Rhode Island's Greater Narragansett Bay Watershed, where OWTS serve approximately 38\% of the population (Bergondo et al., 2005; Amador et al., 2018).

Compromising the health of coastal waterbodies threatens environmental and public health as well as the economy, through mandated beach closures and financial losses in the fish and shellfish trade (Gan, 2002). Without adequate treatment, residential wastewater can also contaminate groundwater with nitrate and pathogens (Ward et al., 2005; Lancellotti et al., 2017).

Commercially-available advanced N-removal OWTS are designed specifically to lower the high concentration of $\mathrm{N}$ in wastewater through biological $\mathrm{N}$ removal (BNR), which relies on sequential nitrification and denitrification. Ammonia-oxidizing and nitrifying bacteria oxidize ammonium to nitrate, which is then reduced to inert dinitrogen gas and nitrous oxide (a greenhouse gas) by denitrifying bacteria, at which point $\mathrm{N}$ is emitted into the atmosphere. Although the configuration and design of advanced OWTS treatment trains (the sequential arrangement of OWTS components) differ among technologies, they all have an oxic zone (for nitrification) and an anoxic zone (for denitrification) to promote $\mathrm{N}$ removal (Oakley et al., 2010). Final treated effluent from the advanced N-removal OWTS is dispersed to a soil treatment area 
(STA), which provides a final opportunity for treatment before effluent reaches the groundwater table.

The use of advanced N-removal OWTS is particularly important in areas that rely on groundwater wells as their source of drinking water, and in coastal areas where groundwater is hydrologically connected to coastal water bodies (Bowen et al., 2007; Lancellotti et al., 2017). The state of Rhode Island requires the use of advanced N-removal OWTS in critical resource areas, which are particularly vulnerable to excess nutrients and/or pathogens present in effluent. State regulations require that the effluent dispersed to the STA ("final effluent") contain no more than $19 \mathrm{mg}$ total N/L (TN; RIDEM, 2018). A similar standard is also used in other areas, including Barnstable County, MA (BCDHE, 2012) and Suffolk County, NY (Tomarken \& Dawydiak, 2017).

Advanced N-removal OWTS do not always produce effluent that meets regulatory standards (Oakley et al., 2010). For example, analysis of data from Barnstable County, MA shows advanced N-removal OWTS fail to meet the $19 \mathrm{mg} / \mathrm{L}$ standard approximately $30 \%$ of the time (BCDHE, 2012). A recent study by Lancellotti et al. (2017) found between 25 and 36\% of the 42 advanced N-removal systems they evaluated in 6 towns in Rhode Island did not meet the $19 \mathrm{mg} \mathrm{N} / \mathrm{L}$ standard, with effectiveness depending on technology. They recommended monitoring of effluent TN concentration to improve treatment effectiveness (Lancellotti et al., 2017), based on the positive impact of monitoring in areas such as Barnstable County, MA. The study by Lancellotti et al. (2017) is the only one to quantify the extent to which advanced Nremoval OWTS meet the Rhode Island state regulatory standard, and to consider how system performance can be improved. 
In this study, we assessed the effluent TN concentration of advanced N-removal OWTS in the town of Charlestown, Rhode Island, USA. Charlestown is a town on the southern coast of the state, where homes and businesses rely exclusively on OWTS for wastewater dispersal and treatment, with a population of $\sim 7,800$ people (U.S. Census Bureau, 2018). While many of the homes are occupied year-round, a portion are only used during the summer months (M. Dowling, personal communication, December 2016). We investigated system compliance with the state effluent standard for TN as a function of technology and home occupancy pattern. We also determined whether wastewater properties (effluent $\mathrm{pH}$, alkalinity, temperature, dissolved oxygen, 5-day biochemical oxygen demand, ammonium, and nitrate) can be used to predict effluent TN concentration. In addition, we assessed how adjustment of underperforming systems affected effluent TN. Finally, we estimated daily and annual mass N loads from systems as a function of occupancy pattern. Our study extends on the work of Lancellotti et al. (2017) by narrowing the geographic range to a single town, expanding the number of N-removal technologies assessed, evaluating OWTS used both seasonally and year-round, and quantifying the mass load of TN from each system as a function of occupancy.

\section{Methods}

\section{Study Systems}

We sampled final effluent from 50 advanced N-removal OWTS serving single-family, residential homes in Charlestown, Rhode Island, USA. Twenty-two systems serve homes used year-round and 28 systems serve seasonally-used homes. We assessed occupancy pattern based on homeowner self-identification, as well as daily flow data from each system. We worked with the Rhode Island Department of Environmental Management (RIDEM) and the Town of 
Charlestown Onsite Wastewater Management department to identify sites that rely on well water for potable water and use a pressurized pump to discharge effluent to the STA. Sites adhering to these criteria were selected after the homeowners agreed to participate in the study. Four Nremoval OWTS technologies were included in this study: (i) Orenco Advante ${ }^{\circledR}$ AX20 (n = 33), (ii) Orenco Advante ${ }^{\circledR}$ RX30 ( $=9$ ), (iii) BioMicrobics MicroFAST ${ }^{\circledR}(n=3)$, and Norweco Singulair $^{\circledR}$ (models TNT, 960, and DN; $n=5$ ). Detailed descriptions of individual technology designs can be found in the Supplemental Materials.

\section{Sample Collection}

We sampled final effluent (effluent to be dispersed to the STA) from each system four times a year from March 2017 to December 2019. Systems used year-round were sampled in March, June, September, and December, and seasonally-used systems were sampled in June, July, August, and September. Systems were sampled in geographical order, allowing us to sample each system at approximately the same time of day during each sampling event. The Advantex systems were sampled at the Recirculating Splitter Valve assembly, while the FAST and Norweco technologies were sampled from the STA pump basin. One grab sample was collected into a clean 1-L plastic bottle. Part of the sample was used for field analysis, and the remainder of the sample was stored at $4^{\circ} \mathrm{C}$ until transported to the laboratory (within 8 hours of sampling) for further analysis. The $\mathrm{pH}$, dissolved oxygen (DO), and temperature of final effluent samples were measured in the field using a Hanna Instruments HI98196 Multiparameter Meter (Woonsocket, RI). A second grab sample was collected into a clean 250-mL plastic bottle and was also stored at $4^{\circ} \mathrm{C}$ until transported to the laboratory for analysis of alkalinity. 


\section{Effluent Analyses}

Detailed descriptions of methods and quality control criteria for laboratory analyses can be found in Ross et al. (2018). Upon arrival at the laboratory, $25 \mathrm{~mL}$ of sample was passed through a $0.45-\mu \mathrm{m}$-pore-size membrane filter and the filtrate was frozen until analyzed for ammonium and nitrate concentration, and $25 \mathrm{~mL}$ of unfiltered sample was frozen for analysis of TN concentration. Ammonium (Weatherbern, 1967) and nitrate (Doane and Horwath, 2003) concentrations were measured colorimetrically using a BioTek Synergy HTX multi-mode microplate reader (Winooski, Vermont). Total $\mathrm{N}$ concentration was determined using the persulfate oxidation method (APHA, 1998), and the resulting nitrate was measured colorimetrically using the microplate reader.

$\mathrm{BOD}_{5}$ was analyzed with an OxiTop BOD 5 measurement system (Weilheim, Germany) immediately upon returning from the field. Within two weeks of sample collection, we measured alkalinity content with an Automatic Titration System (Woonsocket, RI), using an $\mathrm{HCl}$ solution to titrate a diluted wastewater sample.

Summary statistics for the wastewater parameters measured from each technology can be found in Table 1.

\section{Nitrogen Load}

Average forward flow was calculated as described in Lancellotti et al. (2017). We calculated average daily and annual $\mathrm{N}$ load from our systems based on average forward flow data from three years of sampling. Flow data was obtained from the OWTS control panels (elapsed time meter and cycle counter readings for pumps in the treatment train) at each sampling event. 
We multiplied the average daily forward flow by the TN concentration measured at each sampling event to determine average daily $\mathrm{N}$ load. Due to insufficient replication of occupancy patterns across technologies, we grouped systems within occupancy pattern category without regard for technology when investigating flow parameters for seasonal and year-round sites. Annual mass $\mathrm{N}$ load was calculated by first multiplying the average daily load by the number of days in each sampling month for each system to calculate the total monthly load. We then averaged the total monthly load across all sampling months and multiplied that average by the number of months during which the systems are used - 4 months for seasonal sites and 12 months for year-round sites - to quantify the total annual $\mathrm{N}$ load.

\section{Statistical Analysis}

To assess differences in effluent $\mathrm{TN}$ concentration as a function of occupancy pattern, we used a Mann-Whitney U test. We assessed increases in median effluent TN concentration to evaluate differences in effluent TN concentration in underperforming systems before (March 2017 through August 2018) and after (June 2019 through December 2019) system adjustments were made by manufacturers/service providers.

We performed multiple linear regressions to select the best wastewater properties (ammonium, nitrate, $\mathrm{pH}$, alkalinity, $\mathrm{BOD}_{5}, \mathrm{DO}$, and temperature) as predictors of effluent TN. The criteria for wastewater property selection was based on Lancellotti et al. (2017): to include a new parameter in the regression, it had to improve the $\mathrm{R}^{2}$ value by at least $10 \%$ and/or decrease the $p$ value to less than 0.05 , otherwise it was not included in the model. This allowed us to choose the best model with the fewest variables, highlighting the most time- and cost-effective options from a management perspective. We created a correlation matrix for each technology to 
identify variables that covary with each other, and those that covaried $(r \geq 0.70)$ were not considered together in the model.

We assessed differences in average daily forward flow, as well as differences in daily and annual mass $\mathrm{N}$ load, as a function of occupancy pattern using a Mann-Whitney U test.

We used a $p$ value of less than or equal to 0.05 as a measure of statistical significance for all statistical analyses.

\section{Results \& Discussion}

\section{Final Effluent Total Nitrogen Concentration}

We assessed system final effluent TN concentration as a function of technology and occupancy pattern. Technologies varied in effluent TN concentration and in compliance with the $19 \mathrm{mg} \mathrm{N} / \mathrm{L}$ regulatory standard (Fig. 1). Norweco systems produced the highest median final effluent TN concentration (mg TN/L) (median 33.8; range 5.5-60.6; $n=47$ ), followed by AX20 (median 14.9; range $0.6-87.4 ; n=319$ ), FAST (median 13.4; range $2.6-62.3 ; n=32$ ), and RX30 (median 13.2; range $3.0-60.7 ; n=84$ ). Values for AX20 and FAST systems are comparable to those reported by Lancellotti et al. (2017), who evaluated the effectiveness of 42 advanced N-removal OWTS in six Rhode Island towns within the Greater Narragansett Bay watershed between March 2015 and August 2016.

When values for all sampling events and both occupancy patterns are considered, $78 \%$ of RX30 systems produced effluent with a median TN concentration of $\leq 19 \mathrm{mg} \mathrm{N} / \mathrm{L}$, followed by AX20 (73\%), FAST (67\%), and Norweco (0\%) (Fig. 2). Although the proportion of systems in compliance varied among technologies, almost all of the individual systems were capable of producing final effluent at or below the standard at some point during the study. The proportion 
of systems in compliance with the $19 \mathrm{mg} \mathrm{N} / \mathrm{L}$ standard was similar in our study than to those studied by Lancellotti et al. (2017), who found compliance values of $71 \%$ and $64 \%$ for AX20 and FAST systems, respectively.

Our results show that effluent $\mathrm{TN}$ concentration varies as a function of treatment train design. Norweco systems, which produced the highest median TN concentrations, rely on temporal separation of nitrification and denitrification. Both processes take place in the same compartment: intermittent periods of aeration of effluent allow for a switch between anoxic and oxic conditions. In contrast, AX20, RX30, and FAST systems have these processes separated in space, rather than time. AX20s and RX30s rely on a textile media filter as an oxic environment to facilitate nitrification, and an anoxic/hypoxic processing tank for denitrification. Effluent is recirculated between the oxic and anoxic/hypoxic components multiple times before dispersal to the STA to maximize $\mathrm{N}$ removal. FAST systems use submerged, fixed-film activated sludge to treat wastewater. As air is blown into the oxic zone of the FAST systems and effluent is nitrified, it is then transferred into an adjacent hypoxic/anoxic zone where denitrification takes place. Spatial separation of oxic and anoxic components may favor the establishment of microbial communities that are more effective at $\mathrm{N}$ removal. In a study of nitrifying and denitrifying microbial communities of these technologies, Ross et al. (2020) suggested that treatment train design may drive differences in the diversity of microbial communities of nos $Z$, the gene that encodes for the enzyme responsible for the final step in denitrification. Technologies using textile filters (AX20s and RX30s) had communities with higher diversity indices than other designs.

Norweco systems also produced effluent with higher median $\mathrm{BOD}_{5}$ than the other three technologies (Table 1). A high concentration of $\mathrm{BOD}_{5}$ is unusual in advanced N-removal OWTS 
final effluent, since oxygen that is introduced to promote nitrification also promotes microbial oxidation of organic C (Bounds et al., 2004). A high concentration of BOD 5 in final effluent suggests that organic matter is not being oxidized, possibly due to insufficient aeration. This is supported by a lower median DO concentration in final effluent from Norweco systems than from that of AX20, RX30, and FAST systems (Table 1). Effluent from Norweco systems also had a higher ammonium concentration than the other technologies (Table 1), suggesting that nitrification was limited.

Home occupancy pattern did not significantly influence final effluent TN concentration (Fig. 3). Across all technologies and sampling events, the median TN concentration in effluent from seasonally-used systems and for systems used year-round were nearly identical (16.1 and $15.3 \mathrm{mg}$ N/L, respectively). This contradicts the commonly-held belief among industry manufacturers and regulators that a lag time prior to re-establishment of the microbial community at the beginning of the summer compromises the capacity of seasonally-used systems to remove TN (Postma et al., 1992; Baumgaertel, 2016). An assessment of three seasonally-used advanced N-removal OWTS in Barnstable County, MA found similar results: seasonally-used systems produced effluent TN concentrations comparable to those produced by OWTS used year-round (Baumgaertel, 2016). Ross et al. (2020) found no difference in microbial diversity or taxonomy between OWTS used seasonally and those used year-round, suggesting that OWTS maintain similar microbial communities regardless of occupancy pattern. It appears that the accumulation of resources necessary for microbial growth and activity, such as organic carbon and $\mathrm{N}$, when the systems are in use during the summer is sufficient to sustain the necessary microbial communities during periods of non-use. These results speak to the robustness of seasonally-used systems which, even after months of not receiving wastewater, maintain a 
microbial community that is capable of treating wastewater to the same level as systems receiving wastewater inputs throughout the year.

Differences in compliance with the $19 \mathrm{mg}$ N/L effluent standard among technologies were apparent after $\sim 1.5$ years of sampling, at which point the Town of Charlestown's Office of Wastewater Management asked technology representatives and their approved service providers to adjust underperforming systems. After adjustment and a period of equilibration, we assessed effluent TN concentration in the underperforming systems. Measurements made between March 2017 and August 2018 were used to initially identify underperforming systems. We compared those measurements to TN concentrations measured between June and December 2019 to assess the effectiveness of the adjustments made. Out of the 13 underperforming systems, eight had a lower median effluent TN concentration after adjustments, while the remaining five had a higher concentration (Fig. 4). There are several possible reasons for why effluent TN concentrations paradoxically increased for some systems after adjustment. It is possible that the request for adjustment was ignored, and no adjustments were made to the systems. It is also possible that the types of adjustments made did not have a substantial impact on the capacity of OWTS to lower TN concentration in effluent. Lancellotti et al. (2017) also observed no consistent improvement in effluent TN concentration pre- and post-adjustments. They suggested that these results may have been due to an inability of service providers to identify the reason(s) for systems' reduced capacity for $\mathrm{N}$ removal, and/or due to system physical conditions (e.g., uneven settlement of treatment units and/or related pipes, improper installation etc.) limiting the microbial activity responsible for $\mathrm{N}$ removal. 


\section{Predictors of Total Nitrogen Concentration}

We evaluated the best-fit multiple linear regression model for each technology to identify the combination of properties that best predicted effluent TN (Table 2). Ammonium and nitrate, not surprisingly, were significantly positively correlated with effluent $\mathrm{TN}$ for all technologies, in agreement with Ross et al. (2018), who found that the sum of ammonium and nitrate in effluent are strong predictors of TN (Table 2). For AX20 and RX30 systems, ammonium and nitrate concentrations were the only properties involved in the best-fit model (Table 2). Ammonium and nitrate were also part of the best-fit model observed for AX20s by Lancellotti et al. (2017).

For FAST systems, in addition to being positively correlated with ammonium and nitrate, $\mathrm{TN}$ was also negatively correlated with temperature (Table 2). FAST was the only technology to have temperature as a significant predictor. Lancellotti et al. (2017) found that, although effluent temperature did not significantly predict TN, TN concentrations were lower in FAST systems in in winter when ambient temperatures were the lowest, than in spring, summer, and fall. Because the activity of nitrifying and denitrifying microorganisms increases with increasing temperature (Shammas, 1986; Seitzinger, 1988), we would expect to find a negative relationship between temperature and TN in all technologies. Although effluent median temperatures were similar across all technologies (Table 1), FAST systems may provide conditions in which nitrifying and denitrifying microorganisms are more sensitive to changes in temperature than other technologies. For example, the FAST treatment train design relies on fixed activated sludge, and ambient air entrainment into the oxic component where nitrification occurs may have a negative influence on effluent temperatures in winter. Sensitivity to low temperatures has been observed in some $\mathrm{N}$ cycling microbial communities in activated sludge BNR wastewater treatment plants (Randall \& Buth, 1984). 
Effluent TN in Norweco systems was positively correlated with ammonium and nitrate concentrations, and negatively correlated with $\mathrm{pH}$ (Table 2). The negative relationship between $\mathrm{TN}$ and $\mathrm{pH}$ suggests that microbial $\mathrm{N}$ removal in Norweco systems is more effective as effluent shifts from acidic to alkaline conditions. While $\mathrm{pH}$ has varying impacts on communities of nitrifying and denitrifying communities in OWTS, these typically perform best within a certain range: $6.5-8.0$ for nitrifiers and $7.0-8.5$ for denitrifiers (Haandel \& Lubbe, 2007). In our study, effluent $\mathrm{pH}$ values typically fell between $\sim 6$ and 8 (data not shown). The microbial communities in Norweco systems may be more sensitive to $\mathrm{pH}$ than communities in other technologies, but the reasons for this are unclear.

\section{Mass N Load}

The current concentration-based regulatory standard employed by regulatory agencies helps to mitigate $\mathrm{N}$ pollution from advanced OWTS; however, because systems vary in the volume of effluent they discharge, the total amount of $\mathrm{N}$ emitted by OWTS is a better indicator of their impact on the environment (Amador et al., 2018). We calculated daily and annual mass $\mathrm{N}$ load of TN from systems (Fig. 5) using the concentration of TN in effluent from advanced OWTS and the volume of effluent dispersed by OWTS to the STA. Year-round sites produced a significantly higher average daily mass load (g N/system/day) (median 5.3; range $0.01-50.6 ; n$ $=176$ ) than seasonal sites (median 3.7 ; range $0.03-133 ; n=172$ ). The values for year-round sites are lower than those reported by Amador et al. (2018), who assessed daily N loads from 42 advanced N-removal OWTS technologies used year-round within the Greater Narragansett Bay watershed and reported median daily loads ranging from 9.6 to $10.8 \mathrm{~g} \mathrm{~N} / \mathrm{system} /$ day. 
Differences in demographics, wastewater management practices, system effectiveness, and quality of potable water sources likely contribute to this discrepancy.

For both seasonal and year-round systems in our study, average daily forward flow was significantly positively correlated with daily mass $\mathrm{N}$ load, highlighting the importance of flow in determining TN outputs from advanced OWTS. Owners of summer homes in Charlestown do not necessarily live in these homes for the entire duration of the summer: some people may only use them on weekends or for a few weeks during the summer. This results in a significantly lower average daily forward flow from seasonal systems during periods of use. The difference in mass $\mathrm{N}$ load as a function of occupancy pattern, despite the lack of difference in effluent TN concentration between seasonal and year-round systems, indicates that flow controls mass $\mathrm{N}$ load. The median daily flow value for year-round systems in our study $(318 \mathrm{~L} / \mathrm{system} / \mathrm{d})$ was slightly lower than the ranges reported by Amador et al., 2018 (374 - 476 L/system/d), possibly due to differences in homeowner water usage tendencies and/or wastewater management strategies employed by Charlestown compared to those employed throughout the entirety of the Greater Narragansett Bay Watershed.

Year-round systems produced a significantly higher estimated annual mass $\mathrm{N}$ load $(\mathrm{kg}$ $\mathrm{N} / \mathrm{system} / \mathrm{yr})($ median $=2.3 ;$ range $0.20-12.2 ; n=58)$ than seasonal systems $($ median $=0.41 ;$ range $0.020-4.8 ; n=59$ ) - nearly five times less than year-round systems (Fig. 5). The higher annual mass $\mathrm{N}$ load from year-round systems is a function of the higher daily $\mathrm{N}$ load and the longer usage. Our results point to system usage and associated flow - rather than differences in effluent TN concentration - as controlling the differences in mass of $\mathrm{N}$ discharged from advanced N-removal OWTS used seasonally and year-round, and their environmental impact. 


\section{Conclusions}

We found that median effluent TN concentration varied among the different N-removal OWTS technologies we studied in the town of Charlestown. RX30 systems produced effluent with the lowest median TN concentration (mg N/L) (13.2), followed by FAST (13.4), AX20 (14.9), and Norweco systems (33.8). Variations may be attributed to differences in treatment train design, such as whether nitrification and denitrification are separated in space or time. Although technologies varied in the proportion of systems in compliance with the regulatory standard of $19 \mathrm{mg}$ TN/L, almost all of the systems were capable of meeting the standard at some point in the study. Approximately two thirds of the underperforming systems exhibited a reduction in effluent $\mathrm{TN}$ concentration after adjustments, while the remaining systems increased in effluent TN concentration. Wastewater properties that best predicted effluent TN concentration included ammonium and nitrate for all four technologies, with temperature and $\mathrm{pH}$ as additional significant predictors for FAST and Norweco systems, respectively.

Despite the prevalence of similar home occupancy patterns in many coastal towns that experience a significant influx of seasonal residents throughout the United States, our study is one of the first to examine the relationship between home usage and performance of advanced OWTS. Our results suggest that occupancy pattern does not significantly influence the concentration of TN in effluent from advanced N-removal OWTS, and that these systems are capable of withstanding long periods of non-use without compromising performance. Nevertheless, year-round systems produced significantly higher daily and annual $\mathrm{N}$ loads than systems used seasonally, likely due to the higher volume of effluent discharged from year-round systems. These results point to the need to quantify mass $\mathrm{N}$ loading from advanced OWTS to assess their impact on receiving waters. Monitoring of advanced OWTS effluent TN 
concentration in combination with recursive adjustments to meet the regulatory standard, and quantifying mass $\mathrm{N}$ load, will help to mitigate the threat that $\mathrm{N}$-rich wastewater poses to public and environmental health. 
Tables

Table 1. Summary statistics of effluent properties across all sampling events and occupancy patterns for each technology. Units are $\mathrm{mg} / \mathrm{L}$ except for $\mathrm{pH}$ and temperature $\left({ }^{\circ} \mathrm{C}\right)$.

\begin{tabular}{|c|c|c|c|c|c|c|c|c|c|c|c|c|c|c|c|c|}
\hline \multirow[b]{2}{*}{ Property } & \multicolumn{4}{|c|}{ AX20 } & \multicolumn{4}{|c|}{ RX30 } & \multicolumn{4}{|c|}{ FAST } & \multicolumn{4}{|c|}{ Norweco } \\
\hline & $n$ & Min & Med & Max & $n$ & Min & Med & Max & $n$ & Min & Med & Max & $n$ & Min & Med & Max \\
\hline $\mathrm{pH}$ & 267 & 3.8 & 6.8 & 8.5 & 76 & 5.7 & 7.0 & 9.5 & 32 & 6.2 & 7.2 & 7.8 & 47 & 4.5 & 7.1 & 8.6 \\
\hline Alkalinity & 218 & 0 & 75.3 & 391 & 64 & 7.0 & 87.5 & 260 & 20 & 11.6 & 54.5 & 276 & 34 & 70.7 & 179 & 368 \\
\hline Temperature & 275 & 5.0 & 20.9 & 27.1 & 69 & 5.3 & 21.2 & 25.0 & 30 & 14.9 & 21.2 & 24.6 & 46 & 10.4 & 20.1 & 23.1 \\
\hline $\mathrm{BOD}_{5}$ & 209 & BDL & BDL & 100 & 54 & BDL & BDL & 92 & 19 & BDL & BDL & 86 & 35 & BDL & 34 & 94 \\
\hline DO & 257 & 0.8 & 6.9 & 12.1 & 64 & 0.8 & 6.3 & 10.4 & 29 & 0 & 3.8 & 7.1 & 43 & 0 & 1.7 & 5.5 \\
\hline Ammonium & 289 & 0 & 0.5 & 28.6 & 81 & 0 & 0.4 & 51.6 & 28 & 0 & 0.4 & 47.1 & 45 & 0.10 & 19.0 & 53.6 \\
\hline Nitrate & 331 & 0 & 10.0 & 46.9 & 86 & 0 & 8.7 & 33.9 & 30 & 0 & 9.9 & 20.4 & 44 & 0 & 4.9 & 38.0 \\
\hline $\mathrm{TN}$ & 319 & 0.6 & 14.9 & 87.4 & 84 & 3.0 & 13.2 & 60.7 & 32 & 2.6 & 13.4 & 62.3 & 47 & 5.5 & 33.8 & 60.6 \\
\hline
\end{tabular}

$* \mathrm{BDL}=$ Below detectable limits 
Table 2. Parameters for multiple regression best-fit models predicting effluent total $\mathrm{N}$ concentration for each advanced N-removal technology.

\begin{tabular}{lclcc}
\hline Technology & $R^{2}$ & Property & Coefficient & $p$ value \\
\hline AX20 & 0.64 & Ammonium & 1.30 & $<0.001$ \\
& & Nitrate & 0.89 & $<0.001$ \\
RX30 & \multirow{2}{*}{0.72} & Ammonium & 1.01 & $<0.001$ \\
& & Nitrate & 1.02 & $<0.001$ \\
FAST & \multirow{2}{*}{0.92} & Ammonium & 1.21 & $<0.001$ \\
& & Nitrate & 0.79 & $<0.001$ \\
& & Temperature & -0.86 & 0.033 \\
Norweco & \multirow{2}{*}{0.76} & Ammonium & 0.74 & $<0.001$ \\
& & Nitrate & 0.80 & $<0.001$ \\
& & pH & -0.44 & 0.86 \\
\hline
\end{tabular}




\section{Figures}

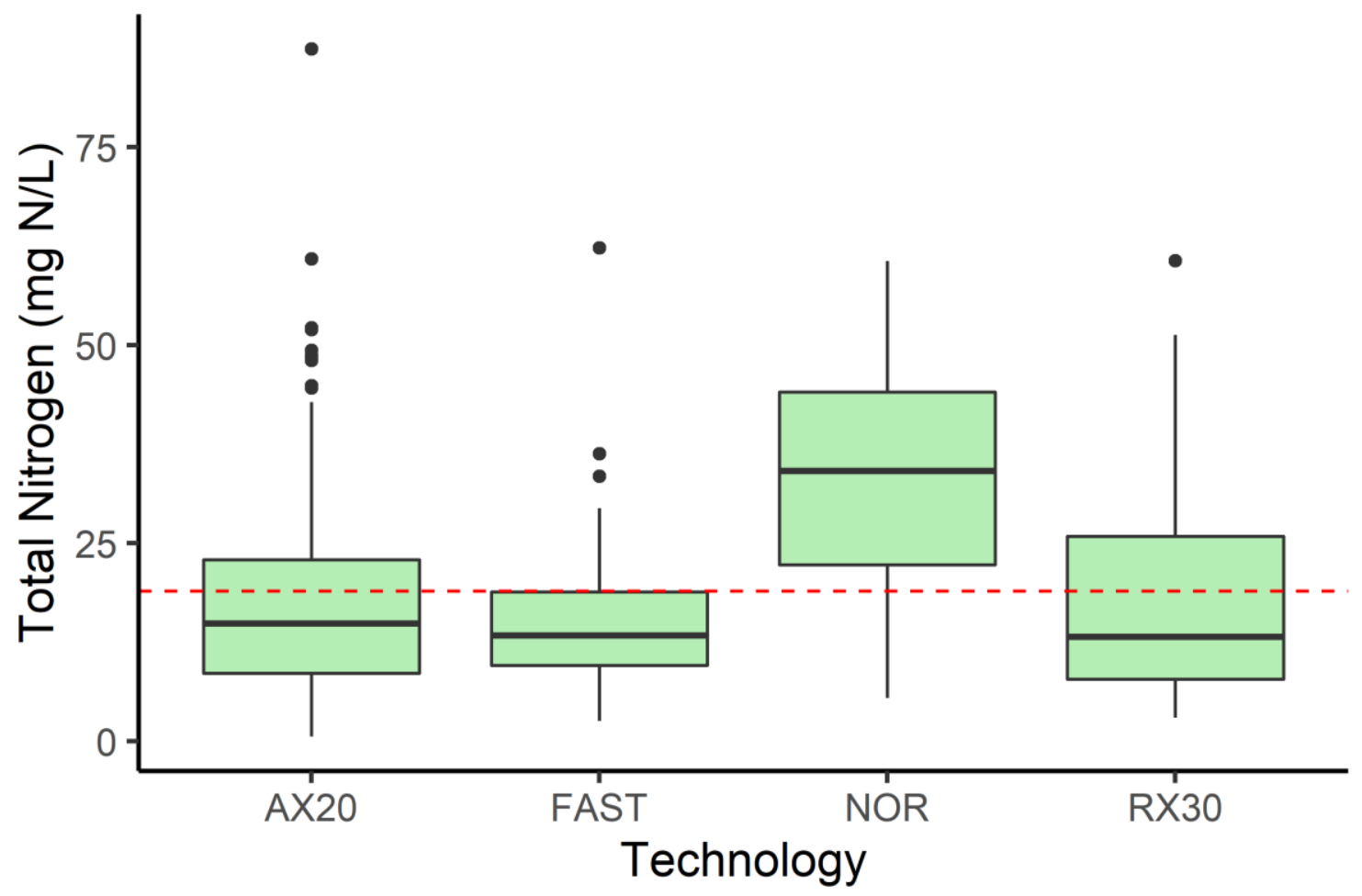

Fig. 1 Final effluent total $\mathrm{N}$ concentration for each technology across all sampling events (March 2017 to December 2019) and occupancy patterns. The red dashed line represents the $19 \mathrm{mg}$ N/L standard required for final effluent. The solid line in the middle of each box represents the median $\left(50^{\text {th }}\right.$ percentile) and the edges of each box represents the first and third quartiles $\left(25^{\text {th }}\right.$ and $75^{\text {th }}$ percentile, respectively). Box whiskers extend $1.5 \times$ the inter-quartile range beyond the edges of the box and the dots represent outliers beyond $1.5 \times$ the inter-quartile range. $\mathrm{AX} 20=$ Orenco Advantex $^{\circledR}$ AX20 (33 systems; $\left.n=319\right)$; FAST $=$ BioMicrobics MicroFAST ${ }^{\circledR}(3$ systems; $n=32)$; NOR = Norweco Singulair ${ }^{\circledR}(5$ systems; $n=46) ;$ RX30 = Orenco Advantex ${ }^{\circledR}$ RX30 (9 systems; $n=84$ ) 

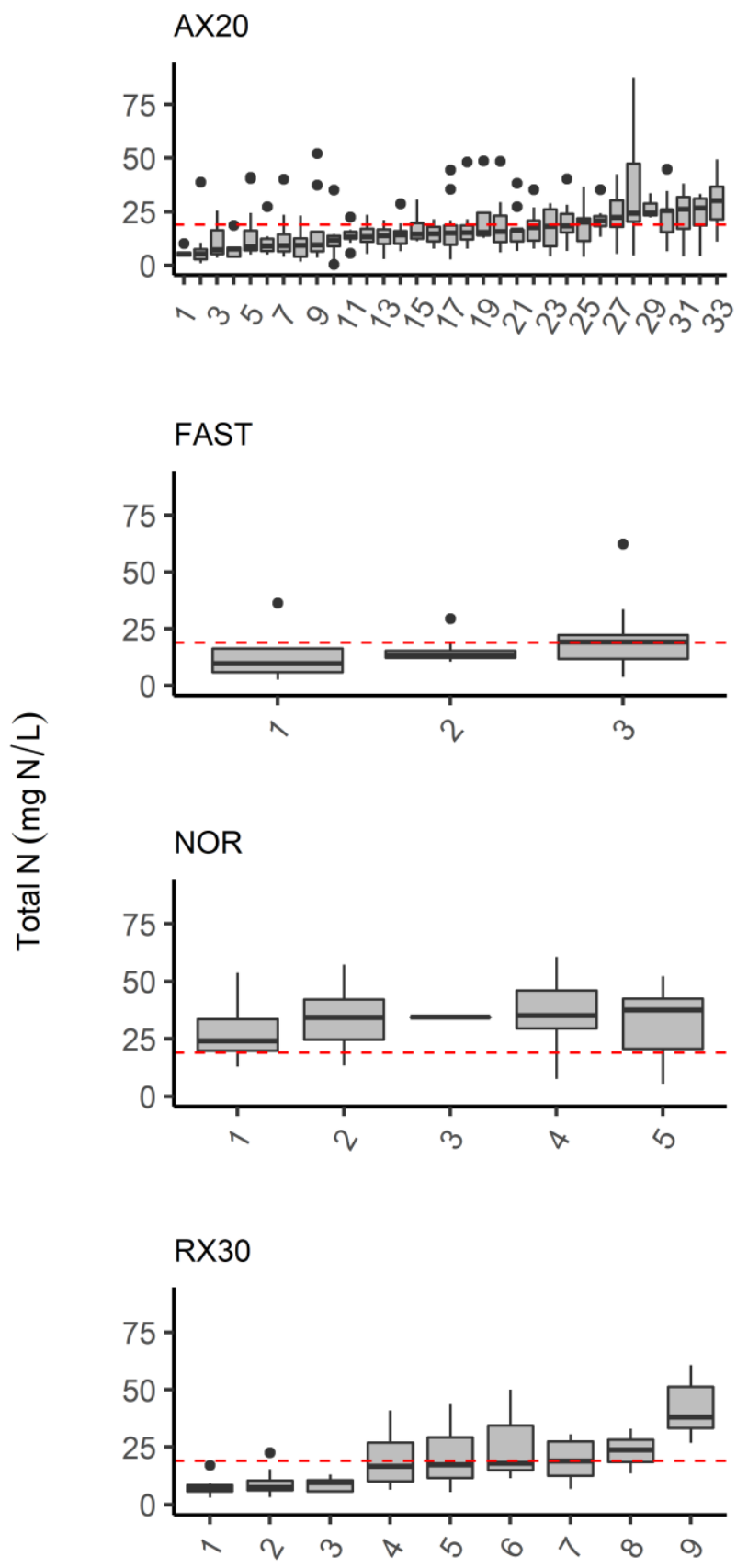

System

Fig. 2 Final effluent total $\mathrm{N}$ concentration for individual AX20 $(n=3-12)$, FAST $(n=9-12)$, Norweco $(n=1-12)$, and RX30 ( $n=3-12)$ systems, in order of increasing median value, across all occupancy patterns and sampling events (March 2017 - December 2019). The red dashed line represents the $19 \mathrm{mg} \mathrm{N} / \mathrm{L}$ standard required for final effluent. Description of box and whisker plots can be found in Fig. 1. 


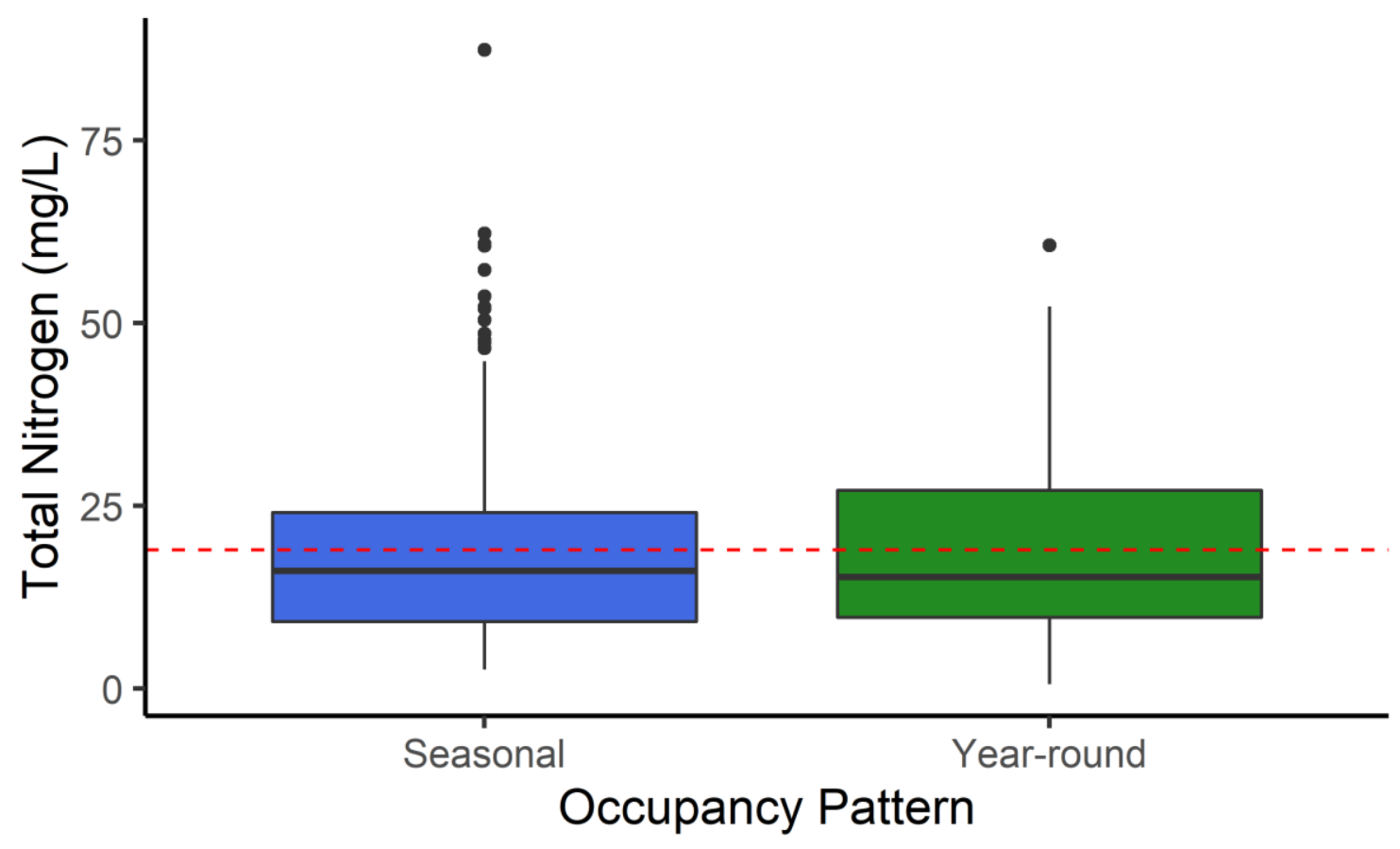

Fig. 3 Final effluent total $\mathrm{N}$ concentration for seasonal (28 systems; $n=273$ ) and year-round (22 systems; $n=208$ ) across all technologies and sampling events. The red dashed line represents the $19 \mathrm{mg} \mathrm{N} / \mathrm{L}$ standard required for final effluent. Description of box and whisker plots can be found in Fig. 1. 


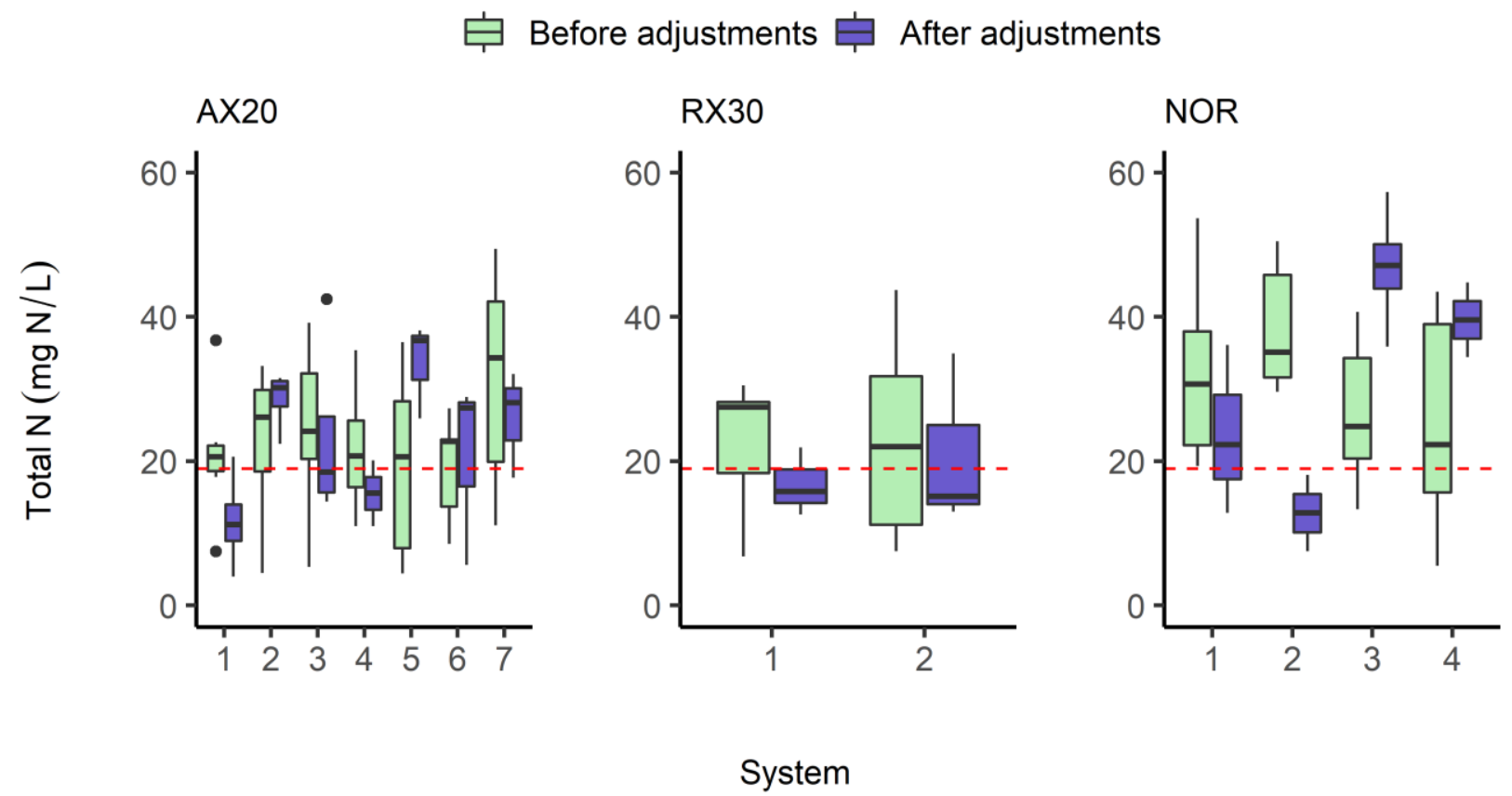

Fig. 4 Final effluent total $\mathrm{N}$ concentration of underperforming systems pre- and post-system adjustments. Data for both occupancy patterns are included. Pre-adjustment data are for samples taken between March 2017 and August 2018, representing the data presented to service providers to help them target underperforming systems. Post-adjustment analyses are for samples taken between June and December 2019, after our request for adjustments was made to these underperforming systems. The red dashed line represents the $19 \mathrm{mg}$ N/L standard. Description of box and whisker plots can be found in Fig. 1. 


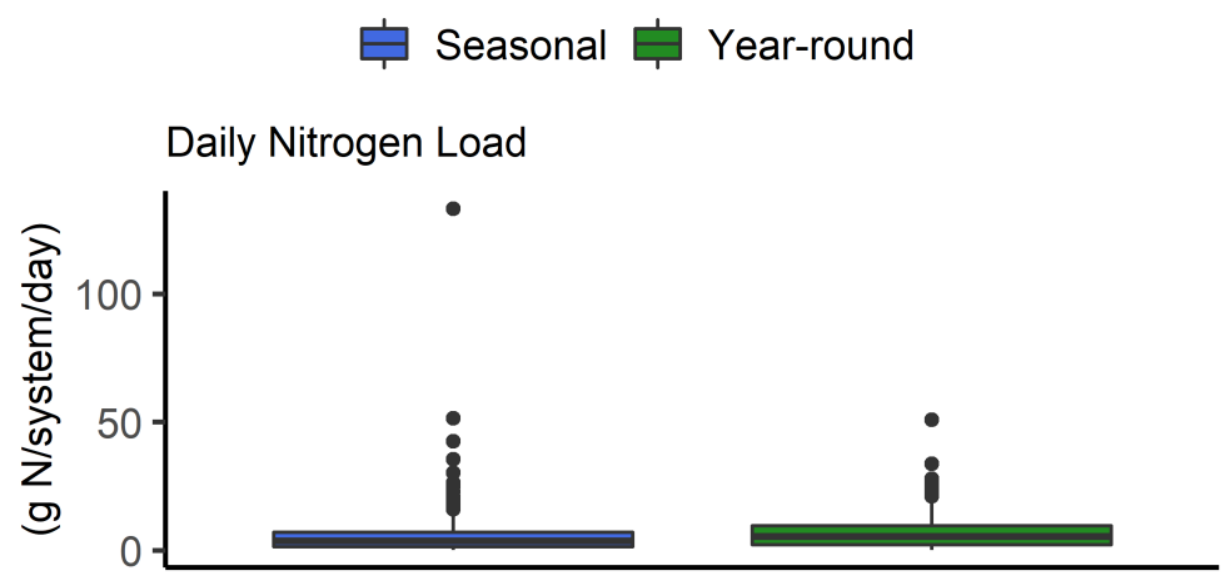

Annual Nitrogen Load

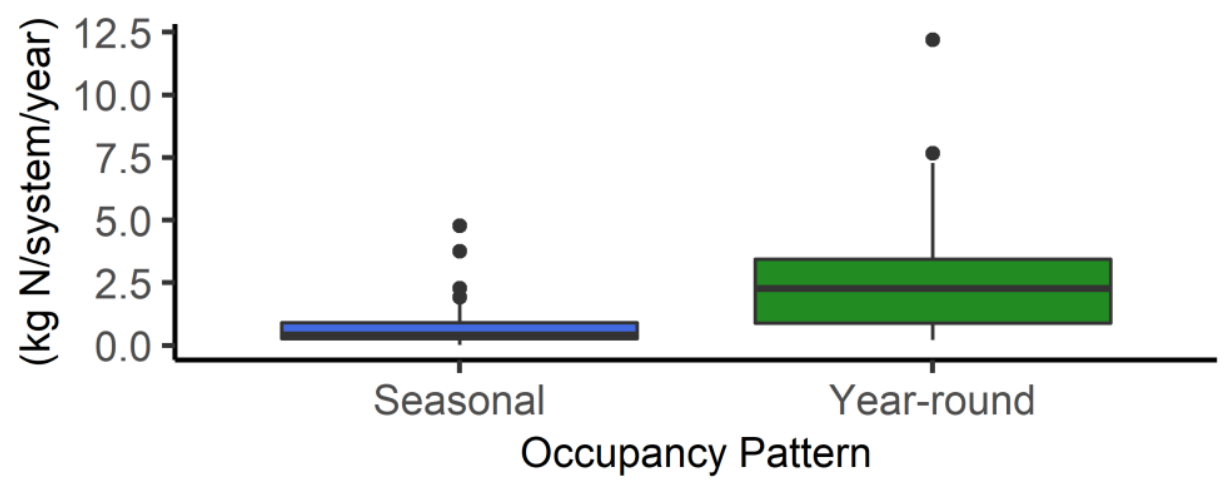

Fig. 5 Daily (top) and annual (bottom) nitrogen load for seasonal $(n=59-172)$ and year-round $(n=58-176)$ systems across all sampling events and technologies. Description of box and whisker plots can be found in Fig. 1. 


\section{References}

Amador, J. A., Görres, J. H., Loomis, G. W., \& Lancellotti, B. V. (2018). Nitrogen Loading from Onsite Wastewater Treatment Systems in the Greater Narragansett Bay (Rhode Island, USA) Watershed: Magnitude and Reduction Strategies. Water, Air, and Soil Pollution, 229(3). https://doi.org/10.1007/s11270-018-3714-4

American Public Health Association, \& American Water Works Association (APHA). (1998).

Standard methods for the examination of water and wastewater, 20, 457-459.

BCDHE. Barnstable County Department of Health and Environment. (2012).

Innovative/alternative septic system tracking. Available at:

http://www.barnstablecountyhealth. org/programs-and-services/ia-septic-system-tracking.

Bergondo, D. L., Kester, D. R., Stoffel, H. E., \& Woods, W. L. (2005). Time-series observations during the low sub-surface oxygen events in Narragansett Bay during summer 2001. Marine Chemistry, 97(1-2), 90-103. https://doi.org/10.1016/j.marchem.2005.01.006

Bounds, T., Denn, G., and Bounds, N. T. (2004). Maintaining and troubleshooting advanced onsite systems: git'er done! 13th Technical Education Conference and Exposition, National Onsite Wastewater Recycling Association. Albuquerque.

Bowen, J. L., Kroeger, K. D., Tomasky, G., Pabich, W. J., Cole, M. L., Carmichael, R. H., \& Valiela, I. (2007). A review of land-sea coupling by groundwater discharge of nitrogen to New England estuaries: Mechanisms and effects. Applied Geochemistry, 22(1), 175-191. https://doi.org/10.1016/j.apgeochem.2006.09.002

Baumgaertel, B. (July, 2016). Seasonal Performance of Innovative/Alternative Septic Systems in Barnstable County. Presented at the New England Water Environment Association 2016 Small Community Conference, North Falmouth, MA.

Carpenter, S. R., Caraco, N. F., Correll, D. L., Howarth, R. W., Sharpley, A. N., \& Smith, V. H. (1998). Nonpoint pollution of surface waters with phosphorus and nitrogen s. (Vol. 8). https://doi.org/10.1890/1051-0761(1998)008[0559:NPOSWW]2.0.CO;2

Doane, A., \& Horwath, W. (2003). Spectrophotometric determination of nitrate with a single reagent. Analytical Letters, 36(12), 2713-2722.

Gan, J. (2002). Clean Coastal Waters. In Journal of Environment Quality (Vol. 31). https://doi.org/10.2134/jeq2002.3630

Haandel, A., \& Lubbe, J. (2007). Solutions in wastewater treatment. Available at:

http://www.wastewaterhandbook.com/documents/nitrogen_removal/431_NR_denitrification_pre requisites.pdf. 
Lancellotti, B. V., Loomis, G. W., Hoyt, K. P., Avizinis, E., \& Amador, J. A. (2017). Evaluation of Nitrogen Concentration in Final Effluent of Advanced Nitrogen-Removal Onsite Wastewater Treatment Systems (OWTS). Water, Air, and Soil Pollution, 228(10). https://doi.org/10.1007/s11270-017-3558-3

Oakley, S. M., Gold, A. J., \& Oczkowski, A. J. (2010). Nitrogen control through decentralized wastewater treatment: Process performance and alternative management strategies. Ecological Engineering, 36(11), 1520-1531. https://doi.org/10.1016/j.ecoleng.2010.04.030

Postma, F. B., Gold, A. J., \& Loomis, G. W. (1992). Nutrient and microbial movement from seasonally-used septic systems. Journal of Environmental Health, 55(2), 5-10. https://www.jstor.org/stable/44534507

Randall, C. W., \& Buth, D. (1984). Nitrite build-up in activated sludge resulting from temperature effects. Journal of the Water Pollution Control Federation, 56(9), 1039-1044.

Rhode Island Department of Environmental Management (RIDEM). (2018). Rules establishing minimum standards relating to location, design, construction and maintenance of onsite wastewater treatment systems. Available at: http://www.dem.ri.gov/pubs/regs/regs/water/owts10.pdf

Ross, B. N., Loomis, G. W., Hoyt, K. P., \& Amador, J. A. (2018). User-Based Photometer Analysis of Effluent from Advanced Nitrogen-Removal Onsite Wastewater Treatment Systems. Water, Air, and Soil Pollution, 229(12). https://doi.org/10.1007/s11270-018-4039$\mathrm{Z}$

Ross, B. N., Wigginton, S. K., Cox, A. H., Loomis, G. W., \& Amador, J. A. (2020). Influence of season, occupancy pattern, and technology on structure and composition of nitrifying and denitrifying bacterial communities in advanced nitrogen-removal onsite wastewater treatment systems. Manuscript in preparation for Water

Seitzinger, S. P. 1988. Denitrification in freshwater and coastal marine ecosystems: ecological and geochemical significance. Limnology and Oceanography 33, 702-724

Shammas, N. (1986). Interactions of temperature, $\mathrm{pH}$, and biomass on the nitrification process. Journal Water Pollution Control Federation, 58(1), 52-59

Sohail, M. \& Adeloju, S. B. (2016). Nitrate biosensors and biological methods for nitrate determination. Talanta, 153, 83-98

Tomarken, J. L. and Dawydiak, W. (2017). Standards promulgated under Article 19 for the approval and management of innovative and alternative onsite wastewater treatment systems. Available at: http://www.reclaimourwater.info/Portals/60/docs/Article_19_IA_OWTS_Standards_Final_ 12-29-17.pdf 
U.S. Census Bureau. (2018). QuickFacts Charlestown town, Washington County, Rhode Island. Retrieved from

https://www.census.gov/quickfacts/charlestowntownwashingtoncountyrhodeisland

Valiela, A. I., Collins, G., Kremer, J., Lajtha, K., Geist, M., Seely, M., \& Brawley, J. (2010). Nitrogen Loading from Coastal Watersheds to Receiving Estuaries : New Method and Application Published by : Ecological Society of America: Nitrogen loading from coastal watersheds to receiving estuaries : new method and application. America, 7(2), 358-380

Ward, M. H., deKok, T. M., Levallois, P., Brender, J., Gulis, G., Nolan, B. T., and VanDerslice, J. (2005). Workgroup report: drinking-water nitrate and health - Recent findings and research needs. Environmental Health Perspectics, 113, 1607-1614

Weatherburn, M. (1967). Phenol-hypochlorite reaction for determination of ammonia. Analytical Chemistry, 39(8), 971-974 